\title{
Changing Trends in Financing of Higher Education: A Critical Review
}

\author{
Mitali Chinara* and Himanshu Sekhar Rout**
}

\begin{abstract}
Education in general and higher education in particular has significant favourable influence on economic development, which calls forth investment in the sector by individuals, households and nation as a whole. However, over the years, many developing countries have showed apathy towards development of higher education. They have reduced public investments in higher education, allowed laissez-faireism, and even adopted policies towards marketisation of higher education. To the extent that the markets in developing countries are 'incomplete' and 'imperfect', the outcomes are also far from perfect. However, to compete in a global knowledge economy and to traverse along the growth path achieved by the developed countries, the developing countries like India have to accord top priority to higher education. To achieve the $12^{\text {th }}$ Plan targets of 25.2 percent of GER by 2017 and / or to reach the global target of investing 6 percent of GDP in education, India needs to explore the innovative methods of financing of the sector. In this context, this review paper traces the changing trends of financing higher education across the globe over the years and the entry of private sector into the arena.
\end{abstract}

Keywords: Higher education; Knowledge economy; Federal grant; Private sector .

\subsection{Introduction}

Higher education has significant influence on economic development of a nation as individuals, households and nation as a whole invest in it. However, over the years, many developing countries have shown apathy towards development of higher education, reduced public investments in higher education, allowed laissez-faireism, and even adopted policies towards marketisation of higher education.

*Associate Professor, Department of Analytical \& Applied Economics, Utkal University, Bhubaneswar, India. (e-mail: mitalichinara@yahoo.co.in)

**Head, Department of Analytical \& Applied Economics, Utkal University, Bhubaneswar, India. (e-mail: hsrout@utkaluniversity.ac.in) 
Market forces have become very active; but since the markets in developing countries are 'incomplete' and 'imperfect', the outcomes are also far from perfect. In fact, in many cases, the market forces produced disastrous consequences. The role of the state in higher education development is critical and cannot be reduced (Tilak, 2005).

To compete in a global knowledge economy and to traverse along the growth path achieved by the developed countries, the developing countries like India have to accord top priority to higher education, research and development. India has already achieved a stage of massification of higher education (Varghese, 2015). The $12^{\text {th }}$ Plan targets to achieve 25.2 percent of GER by 2017, which implies an additional intake or enrolment of 10 million students into the higher education system. Now the question is how to achieve the enrolment targets and who will finance the expansion. The experience in the recent past has shown a fast expansion of the private sector and it is also contributing significantly to the increase in enrolments. India is emerging as an important global player and hence the country cannot afford to have a less developed higher education system. Since most of the developed countries have attained massification of higher education systems mainly through public funding, India too needs to make higher investment in education to reach the global target of 6 percent of GDP through a higher share of the public investments to higher education.

\subsection{Historical Perspective: Methods Adopted to Finance Higher Education}

The compilation that follows aims at tracing the course that higher education financing has taken over a period of time. It can be seen as a collage of patchy but coherent observations made from time to time by many economists, educationists, researchers and public and private agencies in order to find out the sharp twists and turns that financing of higher education has seen and the remarkable milestone transformations that the direction and its composition underwent.

Given the limited nature of resources, their allotment has always been a herculean task for the policy makers. The responsibility to allot financial assistance to various sectors of the economy has always been an arduous task as the resources those are scarce in supply are to be judiciously deployed, if the desired results are expected to show up. Higher education has always been the kind of sector that demands uninterrupted supply of funds to yield results. Therefore studying the financing aspect of higher education assumes importance.

Post World War II, every economy more or less strived to move towards attaining stability, both economic and social. In the pursuit of this stability, every country realised the importance of development of social sector, especially education, if 
long term growth and development was to be brought into focus. Keeping this in the backdrop, many countries started providing financial assistance to education sector with the aim to establish a tradition of up grading and fine-tuning man power to carry the development forward through intergenerational transmission of knowledge. After realising that passing on this legacy is contingent upon the development of education as a strong and resilient sector, governments redirected their financial assistance to revive the sector.

Hence higher education started to get priority that could be marked by the flow of funds to the said sector from every possible source. Apart from government, many non-government sources chipped in to financially support higher education. But, despite the incessant inflow of funds, higher education always seemed falling short of the required funding. Empirical evidences suggest that it was becoming difficult for higher education in almost every country, be it developed or developing, to secure ample funds to keep the system afloat. Numerous reasons can be cited for this lag; but the most noteworthy is that there were glaring differences between what was available and what was needed.

With the flow of time, instruments of financing underwent through many innovative transformations. Some were able to outlast others but failed to be sustainable in the long run. Again, it would be faulty and exaggerated to conclude that every measure surpassed the previous one in its capability to respond to financial agonies of higher education. Though these measures were based on the recommendations of skilled and expert economists, no measure was singlehandedly sufficient for a certain economy. Besides, policy prescription did not have universal applicability. So every country required a certain policy or policy mix to overcome their financial challenges of higher education. That left economists in pursuit of convergence baffled for a while. A critical analysis of the different methods which have been adopted over the years to finance higher education across countries are given below.

\subsection{Philanthropy and endowment income}

During the 1930s, philanthropy emerged as a great mover in the field of financing higher education. The synthesised empirical analysis that used the data of John Price Jones Corporation reveals that Foundations contributed a whopping 77.7\% (in the USA), thus clearly, stood apart as far as financing of higher education was concerned (Harmon, 1931). Almost a decade later, a new trend emerged which was captured by Hollis (1939) in his paper. Endowment income beyond a shred of doubt became the most dominant instrument of financing. Interest emerged as an inseparable aspect of analysing finance since it had a direct bearing upon endowment earnings. The crests and troughs 
seen by endowment incomes were to a great extent attributed to the fluctuations in interest rates. Similarly student fees owing to the depression, hit a rough patch after witnessing an upward spiral. The same fate was met by sales and services as it went through a rollercoaster ride during the pre-depression and depression period (Hollis, 1939). Though philanthropic channels splurged huge amount of financial contributions to higher education, cost of providing education, especially higher education was mounting at such a speed that it was almost impossible for such a source to shoulder the entire financial responsibility. Further studies have shown a spurt in philanthropic contributions to higher education touching the ceiling just after the war begun i.e. in 1940, after which endowment contributions started plummeting on account of falling interest rates. This can be seen as a major setback to the higher education at that point of time and also as a foundation for further down-spiraling. Researchers made predictions that public supported institutions are likely to perform better that the private ones in the face of declining endowment earnings. Governments will have to come forward to sponsor education to keep the galloping costs in control thereby making education available to every deserving student (Soper, 1947). The cost of education was expected to rise considerably and was expected to demand $3 \%$ to $5 \%$ of the entire national income in days to come.

\subsection{Federal grants}

The President's Commission on higher education was set up in 1947 with the aim to do stocktaking, analyse and decide the future course of higher education in the USA. The Commission efficiently brings out its findings in a report published in six volumes out of which volume V is dedicated to "Financing higher education". Prediction that "...the total annual cost for higher education (both publicly and privately controlled) as projected for 1960 will be about \$3,250,000,000" (P.198) necessitated a wellstructured plan to finance this aforesaid amount along with added expense of scholarships and fellowships. Further it states that this estimated amount is expected to claim 1.5\% of their current GNP (P.198). The inflexible tax structure was not able to raise the required supplementary amount. Hence fund were expected to be secured under the assumption that the states will continue to contribute at a rate equal to the pre-War period which again is subject to the condition that national income grew at 1947 level. Finance collected from every possible source such as federal government, sales and services, miscellaneous sources and private gifts and fees left a huge gap of $\$ 638,000,000$ in 1960 in the current operating expense. The Commission recommended that financing capital outlays should be done by the federal government using low interest time-bound loans. In other words, the Commission makes it clear that howsoever 
affluent any particular section of economy may be, it is not wealthy enough to finance the costs singlehandedly. The Commission asked the Federal Government for \$269, 000,000 in 1948-49 which is $\$ 53,000,000$ for general aid and $\$ 216,000,000$ for capital out lay. By 1960, the Federal Government, owing to the policy review would have to grant annually $\$ 854,000,000$ which breaks down to $\$ 638,000,000$ for general aid and $\$ 216,000,000$ for capital outlay (Simpson, 1948). Even the Commission's report did not deny the pivotal role that federal support was expected to play in smoothening the functioning of higher education institutions. Hence the obvious demand for federal support to higher education, though at the cost of looming threat of complete federal control was stressed.

Further researches have hinted at fact that the concept of federal aid has never left the financing scenario of American education system as it was there in some form or the other. Lands, grants for various purposes are some of the channels adopted by federal government to aid education from time to time. Time and again, the assistance provided by federal government became crucial to meet the dire needs arising at the time of emergencies and depression which made the threat of federal control more pronounced. The reason for this being that "they were based, not upon a fixed continuing principle of financial aid extended through and administered by the legal education authorities of the several states, but upon the programs of special Federal agencies"(Simpson, 1948: 340). However, these provisions of federal aids were meant for general purposes. Moving away from this policy, federal government improvised its approach and started giving aid for a defined purpose. This strategy gave birth to legislations like The Morrill Land Grant Act of 1862 and the Smith-Hughes Act of 1917. But Simpson has taken cognizance of the remote possibility of making such legislations for every specific purpose just to avoid the trap of federal control. To this dilemma the paper comes out with a solution which is "Either the Federal Government should, once for all, establish the principle of no aid whatsoever or it should derive a long-range, on-going policy for aid, based upon principles which will assiduously avoid rather than guarantee Federal control over education "(P.341). Subsequently, a survey was conducted in the fall of 1949 by the National Education Association which brought out the need for scholarships and fellowships. "The emphasis placed on this point by privately controlled institutions is stronger (83.1 per cent) than that of publicly controlled institutions (79.5 per cent)." (P.342). This fact again confirms the declining finance to privately endowed institutions for which there arises demand of scholarships and fellowships in larger numbers whereas publicly controlled institutions are relatively less needy owing to the shifting sources of finance. Despite this opinion, there was consensus on financing higher education by federal government (Thomas, 1950). A time came when shrinking funds flow from 
philanthropy had pushed the independent colleges to the brink of shutting down as they were not able to generate enough revenue to cover their expenses, threatening enrolment in such institutions. Different scholars came up with mechanisms of their own to resurrect faith in education amidst financial crisis. In order to overcome this deficiency of funds, Annual Fund Raising was seen as the as the best possible solution which could be executed in a step-wise manner (King, 1951).

In its report of November 1952, the Commission on Financing Higher Education summarised the financial difficulties of higher education as fivefold: (1) inflation, (2) the expansion of educational services, (3) fluctuating student enrolments, (4) need for enlarged and modernised physical facilities, and (5) uncertain sources of income.

Further the research findings pointed to the fact that with continuous rise in enrolment, institutions were faced with the pressure to provide physical facilities those which could not be met from student fees. Federal government at that point of time threw the raft to drowning colleges by providing them with war surplus buildings. But situation improved after that owing to contributions from legislatures, private borrowing, capital-raising campaigns etc. Despite the inflow of funds many of the institutions could not develop up to a desired level. After 1950s, financial support for higher education grew in a large magnitude owing to the inflow of funds from varied sources like contributions from private corporations, alumni contributions, increased tuition charges, rise in incomes of families, scholarship supports extended to the students, increased interest on the part of foundations in providing capital funds to colleges and universities etc. Besides, creation of the Council for Financial Aid to Education, Inc. and federal subsidies to higher education ensured uninterrupted financial flow to higher education (Millet, 1955).

Proposals such as "Proposals for Future Federal Aid" were put forth, which philosophically proceeded to say that federal finance should be limited to the educational projects having national concern. Moreover the grants should be programme-specific in nature to avoid local monopoly of federal support (Davidson, 1955). To counter the assumption that financially weaker states are lagging behind in sponsoring education, Davidson came up with the idea of altering their tax structure as done by richer states. He also expressed his unease about the federal control that might take over the finance scenario (Davidson, 1955).

But federal financing was seen as a potential threat to the free functioning higher education institutions. Hence though the financial crunch faced by universities or universities performing research and training activities to build scientific manpower, crucial for the nation cannot be just brushed aside, public form of financing seemed rather distracting. It would be a worse choice to hand over the controls of research 
expenditure if federal support is to be completely depended on. The latest available figures showed that the three agencies mentioned by Berkner, plus the Atomic Energy Commission, accounted for 97 percent of the total federal expenditures for separately budgeted research and development in colleges and universities in the fiscal 1958 (Kaplan, 1960). To avoid this invasion and reign, universities should receive funds from diverse sources. So despite utmost attempt to avoid federal dominance through diversification of funding channels, the higher education system in America remained steadfastly dependent on federal finance.

On the basis of prediction that with escalating demands in the higher education sector, the generosity of the donors other than the federal government was bound to exhaust, federal government was to soon emerge as the only guarantor of the financial strength of higher education. Precisely put, federal government had to chip in more for higher education given the circumstances.

The goals of resilient national security, better economic condition, and powerful leadership are some urgent requirements too. However, education being the most dependable instrument to ensure attainment of all of these was put by Musgrave (1960) as follows: "Investment in human capital through education is a most important and direct way of accomplishing these objectives." (p.99-100) Regardless of the colossal demand for more federal contributions to higher education, federal government has been tight-fisted due to various macroeconomic factors. Musgrave favoured federal aid over tax relief to finance higher education given that the distracting impact of politics is eliminated and resources are properly utilized.

Hollis (1962) stressed on the imperative need to keep the colleges financially solvent and expanding, which justified a further federal investment in the enterprise. The over-riding justification for such a proposal lies in the indispensable contribution that higher education makes to our economy, our culture, our National welfare, and to our international commitments. The Federal investment can reduce inequality of opportunity among the States without damage to their essential authority or responsibility as a primary source of support and control.

Then there came a time when, researchers opined that federal government had stopped supporting the universities directly. Researchers emphasised the dire necessity of public funds in providing support especially to the universities and its research activities without tampering with the basic tenets of the universities. Especially during the period of fiscal constraint for universities, the lack of cost and other management information can lead to disastrous planning decisions at all government and university levels. Thus, the essentiality of federal financial support for university research can only be estimated, and even these estimates vary widely depending on which, a number of 
reasonable assumptions one can make. Any proposed new fiscal arrangements can have academic implications. For example, future federal-provincial discussions, postsecondary education, including university research, can be regarded as more than a vehicle for fiscal transfers (Sheehan, 1973). But there remained some unaddressed fundamental problems those needed to be remedied soon, as pointed out by Jenny (1975). The first concern is in reaching "the steady state". "The budget and enrolment crunch has hit many public institutions hard, producing massive teaching and research staff layoffs." seemed to be the factor preventing establishment of steady state in higher education finance. The classic tussle between the public and private higher education system is the second concern of the author which led him to put forward the second imperative of higher education i.e. "It must become the public policy of the land, both federally and among the states, that the tuition gap between public and private institutions be narrowed by means of a nationwide system of tuition offset grants or direct student aid that relate to a significant extent to the actual educational costs experienced by institutions." The third concern of the author is "the measurement of higher education" and the complexity associated with it. This led the author to propound the third imperative on higher education which is "During a protracted period of scarce financial resources, it is essential that those in higher education develop an explicit consensus on what are both qualitative and quantitative educational outcomes and on the types of data most appropriate to performance measurement and assessment".

\subsection{Tuitions to supplement federal grant}

Now since the costs were ever-rising, federal support was clearly not enough to cover the expenses of higher education institutions and tuition fees were seen as a reliable source of finance. Tuition fees were not only seen as a medium to shift the burden of costs of higher education but also viewed as a source which can be exhaustively exploited as an option to amass as much of finance as possible from the students seeking higher education qualifications. Meck (1955) expressed his views on student fees as the staple source of finance... "The Commission on Financing Higher Education found that, as of 1950, private institutions as a group and public institutions as a group obtained about 68 per cent and 30 per cent respectively of their educational income from student charges". The factors behind this heavy reliance on student fees were "...(1) the higher cost of education due to decreased purchasing power of the dollar and development of more expensive and specialized curricula; (2) the failure of endowment income and state support to keep pace with expanding enrolments." $\mathrm{He}$ also deals with the question whether there is some possibility of hike in tuition fees. This hike is justified when the students are assured with a better and financially secured future. 
Tuition fees are expected to rise and the students who cannot afford this surge can claim scholarships to meet the financial requirements. In spite of the various ways discussed, paying for education still remained an affliction for an individual student owing to the demand for fees by the colleges in lump sum after the semester begins. Hence pushing the deadlines was seen as an instrument to ease student's burden. Similarly "Pay-as-yougo" plan" (P.171) was seen as another measure. Additionally the colleges and universities should lay a solid groundwork to calibrate themselves to cater to the galloping enrolments without compromising the quality (Meck, 1955).

\subsection{Financing of special institutions}

There were issues like coexistence of both public and private institutions and the plight of Negro institutions owing to discrimination, which led to the birth of United Negro College Fund (UNCF). Separate education institutions for Negroes in southern states had suffered much due to lack of public support and philanthropy was the saviour which had kept the ball rolling. Eventually Negro education started receiving financial support though unwillingly due to the legal backing. On the other hand, private institutions suffered owing to diminishing philanthropic support. Except for some heavily-endowed colleges, other private colleges were at the brink of shutdown as they faced shortage of funds arising due to lack of interest of organised churches, fading philanthropic support, inability of the colleges to hike tuition fees et cetera. The gravity of this crisis simply could not be brushed aside. Hence efforts were made to generate funds in a "community chest fund raising" style to amass as much of funds as possible which lead to "...two philanthropic Foundations, the Rosenwald Fund and the General Education Board, offered to finance the beginnings of such a joint venture. Thus in 1944 the United Negro College Fund was organized...". But the emerging plan got marred by many problems. In response to the first question of which institutions to be included in the list of beneficiaries, "The Fund finally accepted into membership all those institutions which were accredited by the appropriate regional Accrediting agency...". This solved the problem of inflow of finance to the said fund, but raised the dispute of allocation of funds since there was no principle to do so. After many deliberations, "An objective formula was developed" (Trent, 1955) which was modified in 1946 and a new formula was adopted in 1948. Though the formula was not completely flawless, it was the best available. Analysing the ten year performance of the Fund, Trent Jr. states that "In all, the Fund has raised over 25,000,000 for all purposes in the past ten years." Thus accumulating finance initiated by the UNCF, emerged as a very fitting solution to the financial crunch faced by higher education institutions. Hence many institutions remodelled their fund raising technique following the UNCF to reap the benefits 
themselves. But the main difference between the UNCF and the other organisations were the dependence on corporate support, unrestricted individual campaigns, no collective alumni solicitations, limited area of operation, and permission to duplicate solicitations (Trent, 1955).

Grave concern regarding declining flow of funds to relatively small private colleges seemed to have catastrophic impact on these institutions thereby encouraging the economic foretellers to conclude their grim future whereas corporate generosity seems to be the new silver-lining. Inflation-hit education sector had left these private colleges with a dearth of facilities and faculties, compelling colleges to raise their tuition. Further demand for more scholarships, enrolment of Korean War veterans implying lesser subsidies to colleges, surge in research projects in the face of inadequate grants were factors worsening the scenario more.

Stewart (1957) demanded that "sources of financial support must be expanded." He goes on to point out that "...the private institutions in particular must look to philanthropy as a primary source for that additional support." He cites the following developments as reasons for an optimistic future of funds inflow. First being expanding economy and rising philanthropic contributions. In 1955, out of the total donations of $\$ 6$ billion made by Americans 11 per cent was for education. Notwithstanding these fund flows, alumni contributions still amounted for the largest chunk of the contributions received. Efforts to attract more alumni to contribute to their alma mater were done more seriously and efficiently. Corporate too was not lagging behind. Following the conclusion of report of the Commission on Financing Higher Education, universities and colleges have invested much of their energies to draw philanthropic funds through beefing up manpower and organizing fund raisers. Mounting contributions from Parents, communities, churches, bequests, corporate gifts, alumni is a good sign too (Stewart, 1957).

Blum (1958) pointed out the persistent problems that prevailed in the difference between multiplying needs and lagging sources and inequitable distribution of funds received by private institutions on the basis of their academic and infrastructural supremacy. Since there was little scope of fee hike, Tax-credit plans were to come up as a rescuer. Subsidization was prophesied to ease the burden of the tax-payer in the face of proliferation of institutions which would ensure liberty of choice. Hence a "tax-credit plan" was proposed that "...calls for government subsidies to students attending privately supported colleges and (proportionately) to students attending out-of-state publicly supported institutions" (Blum, 1958).

Russell (1960) tried to draw the attention to the upcoming financial needs, while stating "...it seems clear that within the next ten or fifteen years the requirements for 
financial support of current educational and general programs in higher education may well be five or six times the total support currently enjoyed." He predicted that there will be a tremendous increase in the required capital outlay in education. The possible sources of financial support apart from economizing the available resources, mentioned by the author, are "the earnings of endowment funds", "gifts and grants from private individuals, organizations, churches, and commercial corporations", "student fees", and "appropriations from governments". Lastly, federal government more or less emerges as an infallible recourse to financially-struggling higher education (Russell, 1960).

Many authors have proposed that, in order to manage finance better, the existing issues should be resolved. For this purpose the ideas of researchers like Ray, Heneman, Tickton, Millett, Andrews, Clark, Thorp were pivotal. Some insights like reduction of conflicts between governing boards, faculties, colleges etc., reliance on long-term budget, more efficient management, analysis of the sources providing financial support especially philanthropic sources, distributed financing of educational training and research programs, acceptance to manifold financing sources were needed to be resolved to lay a sound foundation.

\subsection{Fiscal support}

Babbidge (1961) favoured taxation as the major source of support to secure what the American society needs - in terms of both quantity and quality - in higher education; and hence opined that work must begin immediately on the development of fiscal policies that will distribute the tax burden effectively and equitably. Amidst all the financial crisis and search for alternatives, corporate donation was considered as the newest entrant to the conventional sources of financing higher education. The dearth of funds for Liberal Arts colleges had the corporate giants of Indiana thinking of a way other than federal finance to sponsor these colleges. Indiana emerged as the herald of an effective educational financing with a total amount of $\$ 7,732,650$ received by the Associated College of Indiana during 1948-1960/61. Following the suit, "In 1958 the Independent College Funds of America, Inc., was established as a coordinating center and clearing house for the 40 state and regional associations. In 1944 the United Negro College Fund, Inc., was organised by 27 Negro private colleges to solicit funds from all sources, particularly from the public." and "In 1952 the Council for Financial Aid to Education was incorporated" (Thompson, 1961).

\subsection{Pre-paid tuitions and student loans}

Later on method of securing prepaid tuitions surfaced as an alternative to tackle persistent financial issues. "Temporary and permanent scholarships were sold at varying 
prices, frequently far below the normal charge for tuition, presumably on the assumption that the large sum of money so collected and invested would realize an income adequate to meet the operating expenses of the institution" (Sack, 1961). In 1825, Dickinson College was the first to implement the scheme. Other colleges followed the suit. But, the program never seemed to yield expected results. Increasing number of state loan programs were seen as an economically effective instrument to buttress the financing system of higher education as they enjoyed the technical edge that was based on multiplier principle. The scheme was highly appreciated by Sack not only for its technical efficiency but also its ability to generate large amount of funds for students from limited assets.

Owing to the criticisms, the scheme of student loan was avoided but the enrolments upsurge, rising expenses, awareness, dearth of scholarship for deserving candidates made it impossible to do so. Consequently "The first guaranty loan program was established in Massachusetts by private interests and with private funds in 1957" (Hill, 1962). "The United Student Aid Funds program", a private, non-profit service corporation, which endorses low-cost, long-term loans by local banks to needy students, was quite successful. No doubt it had attracted more than 100 colleges in no time (Hill, 1962).

Many other economists backed State support of public higher education which offered a fresh perspective to arrive at a potential solution. The costing of higher education becomes more and more elusive as education has very divergent spill-over effects thereby making it hard to compress it into a water-tight compartment of either collective good or private good. However some level of success was attained when the return from higher education was calculated taking higher education as an investment.

\subsection{Fund raising by states}

Based on an approximate enrolment figure of 6.4 million regular-session students, 65 percent in public and 35 per cent in private institutions, Mr. Calkins of the Brookings Institute had estimated that higher education in 1970 will require $\$ 11.1$ billion at 1958 prices. This is approximately 1.6 percent of the projected 1970 Gross National Product. For the year 1969-70 the expected funds for state institutions totalled to $\$ 6,943$ million, from which the "lion's share ( $\$ 3.5$ billion) to be raised by the states" (Sliger \& Beard, 1962). With a thorough examination of empirical evidence, it was thought the states have the ability to amass and spend the huge sum of money warranted for higher education. However, the results could not be generalised to every state of America. Nevertheless, the evidence seems to indicate that the less wealthy states cannot appreciably increase their higher education expenditures without imposing too severe a 
hardship upon them-especially if the funds for these extra expenditures on public higher education are obtained from progressive personal and corporate income taxes (Sliger \& Beard, 1962). Besides, in view of the large direct returns to the student from investment in higher education, it appears equitable for the student to bear a larger amount of the total costs and secondly a heavier burden for states than that projected involves the mildly regressive nature of state (and local) tax structures (Sliger \& Beard, 1962). In order to tackle the problem of finance, state finance proved to be very effective while generating a lingering fear of state monopoly over higher education institutions, hampering the independence and academic quality of the institutions. But the effectiveness of a centralised control in financing cannot be brushed aside. So to pave a middle path, the higher education institutions have to be extremely cautious while dealing with the state while availing funds from them.

The presentation of institutional requests for legislative appropriations frequently suffers from inadequacy of justifications and lack of appropriate supporting information. This is especially true in instances where each institution makes a separate and independent plea to budget officials and legislative committees. Green (1962) finds that it is rare to find budget office or committee staff which is sufficiently well equipped, both in numbers and in the necessary degree of professional knowledge of higher education, to assess bona fide needs satisfactorily and to discriminate among competing institutional demands for funds. This weakness is not difficult to understand, for it stems in many cases from the absence of a meaningful state policy in the field of higher education, inadequate budgets for these offices, and the fact that budget office and committee personnel must review not only requests from colleges and universities but also the requirements of other state departments and agencies. While philosophies and judgments may well differ, there is really no valid reason why decisions or conclusions in this important area should not be based upon a common and recognized body of factual information. Coordinating bodies can and do provide a real service in this regard. With reference again to the Texas situation, this is another area in which the Commission on Higher Education has made a notable contribution (Green, 1962).

Editorial (1962) pointed out three major sources from where the demand for funds originated. Firstly, the institutions were in dire need of funds as they were under heavy pressure to meet the swarming enrolments, to counter the rising burden of infrastructure, to keep the tuition down and to upkeep the quality of education. Secondly there was no doubt a sharp rise in enrolments in colleges but many deserving students were left out because of their financial incapability. Lastly ever-rising enrolments, federal tax obligations of the states, and the regressive state tax system are some of the reasons which created a need for more funds. Federal aid seemed to be the only way out 
of this intricate financial maze as it had a large reservoir of funds and had measures to distribute the funds more efficiently. But the seemingly optimistic solution has a flip side owing to the possible troubles such as: constitutional problems, the danger of control, problems of aid through tax benefits. So the philanthropic channel needed to be finetuned to supplement federal aid. But it was criticized on the ground that it handed down the control of the institutions to the generous philanthropists which again was countered by the argument that in case of corporate support to higher education institutions, public relations are strengthened plus employment opportunities are generated as the companies recruit the students of the institutions. The paper pitches for changes such as: treatment of appreciated property, a tax credit for charitable contributions, removing limitations on deductibility, and other proposals like encouragement to increase tax revenue, permission to the institutions to borrow from a pool of private capital (Editorial, 1962).

\subsection{Student financing in higher education}

When America was rooting for state support along with minimal federal financial backing, Britain was indecisive between loans and grants to be adopted as a means to finance higher education. Given the rising enrolment in Britain, as pointed out by Maclure (1967), requirement of grants will be much higher. This will turn into a headache for the government owing to the need of matching the national income with the mounting finance obligation towards higher education. Hence search for a reliable alternative led to finding subsidized loans for the students instead of the grants. The logic to support loan rather than the practice of forthright provision of grants was: first, switching the policy regarding government financing will not lead to successful replacement without damaging the financial interest of the students and secondly loans will be beneficial to the exchequer, as it would lessen the burden. But the flip side of the loan, as pointed out was that it conceals some technical difficulties such as implication of loan on a girl student, on people with prior obligations and on academic autonomy. Similarly repayment of loan when becomes a tax-like price for going to college, will not encourage higher education.

The issue of magnitude of tuitions in public institutions is indeed a thorny one. In part the thorns grow from the fact that the government has devised no satisfactory arrangement for making people pay after availing public subsidized education. The Zacharias proposal, a special tax dependent on income level of those seeking financial aid to attend college, is an attempt in this direction. Another measure, the loan program, is of limited success in solving the financial problem of higher education. The idea is that if loans are available, then there is less reason for charging low tuitions. Presumably public as well as private institutions could raise their fees. But higher tuition would 
discourage attendance, even if loans are available. People are usually unwilling to accept time payments even with modest interest for advanced education (Heim, 1967).

Some scholars have advocated for different recourses for different countries owing to their financial status and economic climate. Great faith was reposed on the merits of meritocracy as a parameter to distribute the financial assistance to the students of higher education. In general, Merrett (1967) believes that the lower the per capita income of a country, the greater is the utility of income, and therefore the greater the need to establish economically efficient education systems. Similarly, high-income countries should introduce a tax on graduates where their selection procedures are meritocratic, although in the case of these countries they are more easily able to afford education systems or sub-systems where the objective of investment in human capital does not predominate (Merrett, 1967). Some organisational changes were proposed by some to strengthen the tendency towards a more efficient allocation of resources in the area of higher education. The purpose of the organisational changes on which Schultz (1968) concentrated was to improve the possibilities of making optimum allocative decisions pertaining to higher education. The substantive changes relate to economic incentives and information (Schultz, 1968).

There are studies on the income redistribution effects of financing public higher education. To be precise they tried to find out whether the subsidies extended to the student aspiring for higher education are received by the most deserving candidates on the basis of their merit and socioeconomic background. Some low-income individuals have benefited handsomely from the availability of publicly-subsidised higher education. But on the whole, the effect of these subsidies has been to promote greater rather than less inequality among people. To overcome this shortcoming, the system would require a substantial overhaul of the pricing system in public higher education, a realignment of the tax structure, and/or a broadening of the eligibility base for public expenditure programs. In any case, it is clear that whatever the degree to which our current higher education programs are rooted in the search for equality of opportunity, the results still leave much to be desired (Hansen, 1969; Weisbrod, 1969).

A different take on out-dated methods adopted for financing higher education has emerged: There are two distinct considerations which suggest that Schultz's policy conclusions - let the rich self-finance and subsidize the education of the poor - can be challenged. First and most important, while it is obvious that there can be no defense of the present inequitable financing pattern, that does not imply that public educational policy should be the instrument for achieving society's equity goals. A negative income tax is a far superior instrument for that purpose. Second, since those among the "poor" who do go on to higher education will receive the benefits of that education, why should 
42 MANTHAN: Journal of Commerce and Management, Volume 3, Issue 2

they be subsidised at the expense of the children of the poor who do not attend college? The logic of a "first-best" efficient solution-and of the equity argument-suggests that a student loan program is more likely than a subsidy scheme to be efficient and equitable (Krueger, 1972).

The issue of equalisation of educational opportunities remained in vogue for a long time as the researchers continued to dish out alternatives for the nations to pick up when they aspire for better standard of equality and equity in higher education scenario. One possible approach to ensure equality of opportunities, therefore, is a combination of student charges, calculated to provide admissible students with an acceptable rate of pecuniary returns, together with the provision of sufficient financing during school years in the form of long-term loans repayable with interest. The peculiarities of the situation make it possible and desirable to minimise both the risk and expected subjective cost of the investment through the institution of contingent loan programs; that is, loan systems under which repayments are calculated as a percentage of the borrower's annual income. The student-loan alternative is fighting a still undecided battle against more traditional policies for the establishment of equal opportunities, that is, free or low tuition in public institutions with compensating tax support, and student or institutional grants to the private sector. The rapidly increasing and perversely uneven weight of taxation, however, does generate strong pressures toward the consideration of less painful financing methods and payments (by students) for identifiable individual benefits (increased earnings) are clearly more attractive than unrequited levies on the general population. Finally, there is evidence that low tuitions, by creating a state of fiscal stringency that discourages public programs of student aid, may distort enrollments away from equalization. As the cost of going to college goes far beyond the payment of tuition, low income students are induced to attend schools within commuting distance to save on expenses and to limit their attendance to two years to reduce their earnings loss (Daniere, 1972).

When the benefits of existing loan programs for students are examined in relation to parental-income distribution, a disproportionate share of benefits accrues to higher-income classes. According to Tweeten (1972), this is not due to the perverse intents of administrators but rather due to the ubiquitous and fundamental conflict between goals of equity and efficiency with public programs. The conflict grows out of limited public funds and the desire to use these funds in the best way possible. The funds generate the greatest income per public dollar spent when focused on persons who are highly motivated and able. But these individuals frequently prosper even in the absence of the program, and they (or their parents) are likely to be at the upper-income end of the group eligible for the program (Tweeten, 1972). 
African countries also experienced some major issues concerning financing of higher education. Two major problems confronting African nations as a whole and Nigeria in particular, are (1) the cost of education and (2) the problem of the efficient utilization of the resources of higher education (Nwacukwu, 1977).

Apart from the quality versus equity tussle, keenly observant scholars also spotted the cracks beset in the teacher education which constituted a significant part of higher education. How well is teacher education funded? Every dean, department chairperson, and faculty member in teacher education probably believes that his or her program is seriously underfunded. The appalling fact is that, even though teacher education has been an abundantly researched field, teacher educators usually continue to deal with abstractions rather than facts in arguing for increased funding. Even though state legislatures provide funds in addition to the tuition collected to enable the delivery of reasonably qualitative educational programs, many institutions apparently siphon off a large portion of the dollars intended to help prepare teachers and to provide for their continuing educational needs (Orr, 1979; Peseau, 1979).

The access dimension of higher education has been examined in the context of student financial aid. An important concern has been whether student financial-aid programs diverted resources from other sectors of the economy where they might have been more helpful in stimulating economic growth. That is, did concern for equity conflict with economic growth? Although economists generally view these two goals as conflicting, it is possible that redistribution and economic growth complement each other in human-investment programs such as education. Educating talented students can contribute to the future growth of the overall economy. If such students are too poor to finance their own education, then a program of financial aid is certainly helpful. In such cases, the pursuit of equity through redistribution policies would seem to encourage economic growth (Hansen, 1983). With rising burden on the federal government, student loan programs were seen as an alternative far more convenient and economically feasible than other options. For this reason student loan schemes were extremely popular for the developing as well as developed countries. So more or less student loan schemes owing to their ability to blend into any economic conditions were as sold out an idea as a hot cake. But soon the illusion was demystified since the recovery rates across the globe were disappointingly low and millions of finance went right into the black hole. The situation became so hopeless that many loan schemes were stopped midway and governments of many nations were bound to either substantially reduce or totally withdraw financial support extended through the student loan schemes. As baffling as it may sound but it brought the economies to such a situation of financial crunch that provision of financial backing to higher education was again at stake. Culpability was 
elusive as usual. There were voices in favour of handing a larger chunk of financial responsibility to the governments as they were believed to be the only agent of the economy having financial ability and credibility to pull the major task of keeping the education sector viable without disturbing the balance of the economy. Some endorsed privatisation as a convenient option. But the financial strain remained.

Developing countries were worst hit by the debacle of student loan schemes. Some bitter experiences of the loan programme of Asian and African countries such as People's Republic of China, India, Singapore, Botswana, Uganda, Ghana, and Nigeria were furnished by eminent research scholars such as Shouxin and Bray, Tilak, Shantakumar, Mokgwathi, Kajubi, Kotey, and Chuta respectively. Student loans have been abandoned in Indonesia and Sri Lanka. One of the first schemes in Africa, the Ghana University Students' Loan Scheme, was introduced in 1971 but abandoned after less than a year due to political opposition and the fall of the government that had introduced loans. But this early experience offers some interesting lessons. Despite the fact that loans were advocated in Ghana on grounds of social justice, there was widespread hostility to the scheme, particularly from the politically vocal student body. In fact Williams (1974) suggests that the failure to mobilise public opinion on the advantages of loans, and a feeling among students that they were being made 'scapegoats of the country's failure to control higher education costs' were among the reasons why the student loan scheme ran into such immediate difficulties. Loans were re-introduced in Ghana in 1975 but still faced problems of massive default. Kotey (1992) has suggested ways for loan recovery, by linking it with the social insurance system and giving the responsibility for collecting loan repayments to the Social Security and National Insurance Trust (SSNIT).

Several countries were also trying to develop tests to identify financially needy students in order to target student aid more effectively, which is one of the recommendations of Albrecht and Ziderman for improving the efficiency of student loan programs. Malawi gave the responsibility to universities for selecting students from the lowest income families to receive loans and Uganda proposed to offer subsidised employment to them. Selection on the basis of family income was also attempted in Nigeria and Zimbabwe, Indonesia and the Philippines. In India also, student loans were intended for low-income students, but Tilak argues that a system of discriminatory pricing (under which students from wealthy families would pay higher fees than those from low-income families) would be more equitable than student loans. However, this would require accurate and sensitive tests of family income which are difficult to devise and administer. Very elaborate assessment of family income is used to determine eligibility for student loans in Hong Kong, but accurate data on family income is very 
difficult to obtain in most developing countries. This problem also arises in the case of proposals for income-contingent loans, which are advocated by Barr (1989 and 1991) and discussed by Albrecht and Ziderman. Developing countries in Africa and Asia have not yet attempted to devise variable repayment schedules or repayment based on income levels, nor to offer automatic postponement of loan repayments for the unemployed or those with low incomes, as is the case in Australia, Sweden and the U.K (Woodhall, 1992).

Meanwhile the controversy associated with subsidies as a measure to ease the burden of higher education for low-income families through transfer of resources from higher-income individuals toward lower-income individuals remained unanalysed. But many studies have found that public support for higher education involves transfer of resources from lower-income individuals to higher-income individuals. Standard models of redistribution or public provision of goods and services under majority voting predict transfer of resources in the reverse direction and are thus unable to provide an explanation of the above problem. Fernandez (1995) and Rogerson (1995) have shown that within a simple setting, transfers of resources from lower income groups to higher income groups are possible if individuals vote over the extent to which they subsidise education. If education is partially subsidised, poorer individuals who are credit constrained cannot afford to obtain an education and are thereby excluded from benefiting from the subsidies. We find that increased inequality in the income distribution makes it more likely to obtain a net transfer of resources away from the poor (Fernandez, 1995; Rogerson, 1995).

\subsection{Returns to education}

Despite the fact that calculation of returns to education is an uphill task, much of the motivation to invest in education depended on the returns received. Many scholars also attempted to draw attention towards this cost and return aspect of higher education before investment. Governments readily accepted this approach and extensive researches were done to arrive at some workable results even if there was no means to test the accuracy of the results obtained. Government spending on education would ideally be directed to those levels where the gap between social and private returns is highest. Though estimated returns suggest that this gap is greatest at the primary level, estimated returns do not take into account unmeasured social benefits of education. These social benefits could be substantial in certain components of higher education. Moreover, the social benefits to primary and secondary education may be declining in developing countries as more students complete these levels; and the social benefits to higher education could be increasing, for example, with the opening of many developing 
economies to global markets and competition. If unmeasured social benefits to higher education are (or could become) high enough, the ranking of social returns as currently measured could change. Thus, it is not obvious that reallocation of public resources for education from higher to the primary (and secondary) levels is warranted. Moreover, even if the social benefits of higher education in most developing countries are not high today, there is ample scope for reforms of financing and governance that would enhance the quality and improve internal efficiency, thus greatly raising social benefits. User charges would also help ensure that a higher proportion of public funds in the higher education field could go to the public goods of basic research and graduate training. Since these public good activities are rarely produced outside university settings, they actually tend to be the first to suffer if public and political demands lead to higher than optimal spending on undergraduate training (Birdsall, 1996).

\subsection{Private verses public financing}

Then came a time when there was a war waged between Private versus Public Financing of Higher Education. Both forms of financing had ample supporters to keep the debate alive and kicking for a long time. Advocates of private financing often claim that education, specifically higher education, yields private, or individual, as well as social returns. Furthermore, it has a privileged clientele drawing on tax revenue paid by society at large. Consequently, public funds are more justly invested at the primary and secondary levels. Beyond these equity issues, plural income sources insure university autonomy, efficiency, responsiveness, pluralism, diversity, client choice, and client responsibility. At an extreme, followers of Milton Friedman regard public subsidies as another "indiscriminate extension of governmental responsibility" (Friedman, 1962). Advocates of public funding, on the other hand, argue that all levels of education is a state responsibility. Externalities, both economic and non-economic, make higher education mostly a public good, and only public funding can guarantee equal access (Levy, 1982).

After acknowledging that there undoubtedly was the need of private sector to contribute along with the public sector, given the gross inadequacy of funds in higher education sector, there was an open call for attaining a broader base for financing higher education by many scholars working on the trend of rapidly growing tendency towards privatisation. Higher education offers ample opportunities for participation by both private and public sectors (Mathew, 1996). The inadequacies or rigidities arising from exclusive reliance on either sector or any one form of private initiative can and should be corrected by diversifying the mode of financing. Under no circumstances, however, the entire cost of providing higher education should be recovered from the immediate 
beneficiaries, which is exactly what the self-financing colleges seek to accomplish. Instead, apart from the students currently enrolled, as many supporting agencies as possible such as alumni, industry, philanthropists, foundations, trusts and endowments should be involved in financing education (Mathew, 1996).

The adoption of a prepaid tuition program involves projections of the incremental start-up costs of the plan, the rate of growth in tuition, the rate of return on endowment, and enrolments over time. While such projections are not easy, they are considerably simplified by the probability that the rate of growth of endowment will exceed inflation. Thus, if increase in tuition does not exceed the rate of inflation, if enrolments are expected to decline, and if the marketing costs are not especially high, the plan will succeed. Assuming that private institutions offer special services that are not provided by public institutions, if a family wishes its child to attend a private school, the family perceives that the private school is special and is worth the tuition charged. A prepaid tuition plan in private education is one innovative approach to coping with the changing character of the market for private education (Bloch \& Hinshaw, 1997).

\subsection{Entry of private sector}

There were some the long term hurdles which cropped up in financing higher education as the government prepared itself to cater to the increasing demands of the enrolments in the US. Universalization of higher education proved to be too lofty a goal to accomplish in the presence of scarcity of resources. As Kane (1997) pointed out...the Administration has proposed two major initiatives for higher education: an increase in federal grants to low-income undergraduates and various forms of tax relief for those with family members in college....(in the US). The President too had proposed two major changes to the way higher education was being financed: an increase in Pell grant spending of roughly $\$ 9$ billion over the next five years and new tax credit and tax deduction for college expenses, estimated to cost approximately $\$ 36$ billion over the same period (Kane, 1997).

During this time, the private sector made an entry into the education sector, though its progress was far from being friction free. The private sector faced some distinct challenges, as pointed out by Mulugetta et al (1997). In addition to concerns linked to the mechanics of institutional aid, they include the alarming rise in the proportion of loans within student's financial aid packages. Reliance on loans to finance undergraduate private education may also produce detrimental effects on student retention as well as the job seeking behaviour of graduates. 


\subsection{Innovating financing: Vouchers as means of financing}

The process of designing alternatives to finance higher education never ceased as many researchers, from time to time, kept on inventing advanced and up graded instruments. One such instrument designed was voucher. Vouchers became an instant hit with the policy makers those who wanted to ensure that students attended higher education institutions irrespective of their family incomes without unnecessarily straining the distribution system of the country. Many advocates of school voucher policies increasingly cite as favourable precedent the effectiveness of direct student aid program in higher education. They maintained that federal and state direct student grant program constitute a legal voucher and do not violate federal or state law. Voucher advocates also declared that such governmental policies have successfully expanded student choice without detrimentally impacting resources of public higher education. Today, growing disparities in expenditure per student continue to favour private-higher education while low-income students' access to private institution remains limited. This is occurring despite the fact that greater amount of federal funds per students are now expended through direct student grants and subsidized loans for students in private colleges than for students in public institutions. Alexander (1998) found that state governments have followed federal policy directives in removing many legal barriers to providing aid to private institutions and creating voucher schemes for financing higher education. Even with means test methods designed to concentrate greater assistance on lower-income students, the voucher programs create disparities in favor of private institutions and correspondingly appear to contribute little to expanding educational opportunities or choice. As greater proportions of state voucher programs also shift from need-based to merit-based aid, it may be anticipated that lower-income students may have further diminished opportunities (Alexander, 1998).

\subsection{Changes in Europe}

Meanwhile Europe seemed to have undergone many structural changes. Right from the enrolments to finance, every aspect went through a transformation to take higher education to a whole new level. Eicher (1998) has listed out various points with regard to financing of higher education: Student participation in the financing of their studies is still lower than the optimum as experienced in many European countries; tuition fees are increasing in different forms and methods. This trend will probably continue because the financial burden on public authorities is generally considered too great and for the reasons of efficiency and equity as already mentioned. In most countries, student aid systems must be re-thought and amended in relation to the evolution of fees. A harmonisation of fees and student aid systems is highly desirable if 
one wishes to continue to build a unified Europe. Many problems are still being debated, especially the level of tuition fees and the ways of reimbursing loans (Eicher, 1998).

\subsection{Current concerns}

Ever rising demand for funds towards higher education expenses made the federal government chip in some more financial assistance. But scholars did not shy away from examining whether the investment in higher education was justified by its contributions to economic development. While economic benefits cannot and should not be the sole basis for measuring the contribution of higher education to the states, it must be kept in mind that public support for colleges and universities provide immeasurable benefits to the intellectual and cultural development of citizens in the states and communities these institutions serve. Besides, higher education also contributes to certain dimensions of state economic development (Jones, 1990). The claim that education is both a consumption and investment good seems particularly true when applied to higher education. The finding that state support has a positive short-term effect on the economic outputs of a state is particularly significant for decision makers attempting to determine the economic contribution of higher education. The evidence presented by Jones supports the contention that higher education has positive consequences in terms of tangible indicators of state economic performance: earnings, exports, and gross state product. It could be argued that these items add value to the economy and, at the same time, add value to individuals and improve the overall quality of life. Further analysis may provide insights into what types of educational activities yield the greatest economic return and whether one particular educational delivery system has a more significant impact than another (Strom, 1999; Feiock, 1999).

The changes infused into the higher education system were inexorable as there were numerous demands for amendments in many areas of higher education. Changing policies at the radical level and demographic transition were some of the major drivers leading to search for alternative ways of paying for college. It also generated much curiosity among scholars as they dished out many alternatives of their own keeping the economic setting of the nations and the need of the hour in mind. Hence scholars prescribing a seemingly potential but single strategy for every nation were castigated. The conclusion drawn is that there cannot be one alternative financing strategy, but rather a matrix of opportunities put together by and for students in a sophisticated way. The responsibility for determining strategy needs to be shared between the financial aid professional who represent an institution wishing to recruit students and the individuals who hope to achieve their educational aspirations. "As they take on these new roles, aid officers should adopt a total quality management approach to management, incorporating 
attention to their customers, effective teamwork, management by fact, planning, and continuous quality improvement" (Kurz, 1995).

Since redistribution effects of higher education were always favourite topics for discussion, assessment of contributions of higher education to enhance the equity and availability of equal opportunity was under scrutiny. Public subsidies to higher education are commonplace in all developed economies. Attempts to justify this phenomenon typically emphasize market failure arguments such as positive externalities from higher education, capital market imperfections preventing people from financing higher education on a loan basis, non-existing insurance markets against educational risks, and interdependent individual preferences leading to relative income concerns. In the policy debate, on the other hand, higher education subsidies are frequently defended by equity oriented arguments like promoting fairness and facilitating access to higher education for children from low income families. Yet, it is a now well-documented fact that public involvement in higher education financing constitutes redistribution from the poorer to the richer part of the population. Moreover, children from higher income families are more likely to engage in higher education and to choose more cost intensive branches such as medicine than children from lower income families. Against the view that public higher education financing has a regressive distributional impact, it has been argued that in presence of an income tax system, on an average, burdens on high income individuals more heavily than low income individuals, university graduates are likely to pay back part or all of received subsidies in the form of higher taxes. University graduates can be expected to pay more taxes because higher education leads to larger endowment with human capital translating into an increase in labour earning and, henceforth, income taxes. Therefore, Wigger (2001) suggests that rather than combining a progressive income tax system with subsidies on higher education, which is a common practice, higher education subsidy should, for equity reasons, be lowered and, at the same time, labour income tax should be decreased. Lower education subsidies will increase higher education investment. However, low income taxes will increase them and will strengthen incentives to use the output of higher education productively (Wigger; 2001).

Interestingly, another study revealed that subsidies imply reverse redistribution (Beviá \& Iturbe-Ormaetxe, 2002). All evidence points unequivocally to the regressive effect of present university finance mechanisms in all countries in the world. This means that the poor pay for the education of the rich. The policy implication is that imposing student fees would promote efficiency and, paradoxically, equity. Based on the existing evidence, it is argued by Psacharopoulos (2008) that the most efficient and equitable way of financing higher education today is to allocate public funds to the universities in an indirect way. This is to let the students decide what university will get funds, and what 
other university may close because of lack of funds. The strong incentives introduced by such a system would ensure efficiency and accountability among students and professors, without resorting to petty regulations. And when more money is put in the hands of the poorer students, equity would be redressed. Over two centuries ago, Adam Smith (1776) proposed a variant of this scheme to make Oxford dons more responsible in their teaching (Psacharopoulos, 2008).

Jacobs and Wijnbergen (2007) in their study have focused solely on efficiency properties of the various financing regimes. The analysis of distribution concern will add additional support for an equity-preparation model as opposed to straight education subsidies. This is because the average tax payer, who is paying for the education subsidies, will have a lower lifetime income than the average graduate who has received them. The basic argument applies to all levels of education. But because most countries enforce universal school enrolment, at least for children up to the age of 16 or 17, general taxation is probably more reasonable a vehicle for recouping expenditure on primary and secondary schooling. Through universal school enrolment, all tax payers have been recipients of the benefit of public expenditure on primary and secondary schooling. Financing higher education through general tax revenue, on the other hand, has adverse distributional consequences (Jacobs \& Wijnbergen, 2007).

Further other researchers advocated for tax financing as a staple alternative for funding higher education. Though later they started to believe that tax funding alone was not sufficient or feasible for every economy for which a blend of multiple strategies should be adopted by the nations as per their economic positions (Barr, 2003).

The economics of education literature contains proposals for combining income taxes with higher education subsidies in order to limit the tax distortions on investment in higher education. This analysis also suggests that higher education subsidies are not second best, but third best at the utmost (Wigger, 2004).

Cost sharing became the instant favourite and intriguing topic for the researchers as they tried to find out who should bear the burden of finance or who should pay? It was quite perfectly comprehensible that the liability of paying for higher education cannot just be squarely enforced upon either government or the higher education aspirants. The dilemma has led many scholars to probe into this area of education and come up with many interesting observations worth-noting. The worldwide trend toward some greater cost-sharing -i.e. increasing tuition and diminishing levels of public subsidies, at least to non-needy students- seem inevitable. The inevitability does not reflect any triumph of World Bank policies, nor of market capitalism, and would not necessarily be the preference of many thoughtful analysts who believe in the market but who also foresaw problems in the increasing privatisation of higher education. However, there seemed to 
52 MANTHAN: Journal of Commerce and Management, Volume 3, Issue 2

be no escape from the conclusions that: (1) higher education in the future will need vast additional resources, particularly in developing countries, and (2) the only alternative to more of the burden being shifted to parents and students is for there to be very large increase in taxes, progressively raised....Without additional cost sharing, it is almost certain that enrolments will be restricted, and/or the higher education that is available to the masses and still "free" will be of increasingly lower quality (Johnstone, 2003).

For Southeast Asian higher education systems, the on-going growth in the private sector is likely, bringing with it the need for more effective regulation. The growth of the private sector, including the rise of transnational delivery, some of which is of good quality, and some of which are no more than diploma mills, will pose greater demands and impose greater costs on already pressed regulatory agencies throughout the region. The equity effects will need to be carefully monitored, given the data on highly differential access to higher education in several parts of Asia. Quantitative expansion, however, does not exhaust the calls on the public purse. Both China and India, as emerging world powers, have ambitions to build world-class universities as part of their modernization and development agendas. Similarly Malaysia and Viet Nam's plans to develop APEX or model universities are ambitious, in scientific and financial terms, although Viet Nam's plans are linked to outside support, at least initially, from countries such as France, Germany, and US. As argued in the ADB report (2012), not all systems are equally able to build solid foundations for world class institutions. Some might achieve better results by putting more effort into building quality and equity across the system, and delaying the costly, if enticing, goal of having a world-class university as soon as possible. Achieving this goal will not come cheap, however. The rich mix of facilities that characterize research universities (extensive research libraries, information and communications technology and computing facilities, high-quality researchers and students) places them largely beyond the bounds of the private sector, so states wishing to develop such institutions will need to invest further in both creating and sustaining the necessary facilities, as well as fostering a culture of independent research that is the sine qua non of top-tier research institutions. China has thus far shown greater resolve than India, but both will need to make substantial, and continuing, further investments to create this elite tier of institutions (Yang and Welch, 2011). The socially differential effect of the moves to shift costs from the state to families and individuals needs closer investigation and more attention, including by governments within the region. If the trend towards cost sharing without effective social protection measures to support the disadvantaged continues, the result will be a mere cost shifting, and the impact on equity will be profound, with major losses in terms of both social inclusiveness and equality, and economic efficiency (ADB, 2012). 
The only substantial and continuing source other-than-governmental support of higher education generally is cost-sharing. Cost-sharing is both a statement of fact-that higher educational costs are necessarily shared among governments (mainly taxpayers), parents, students (mainly through part-time employment and loans), and philanthropists or donors - as well as a term used to describe a worldwide shift of the costs of higher education from a predominant or even an exclusive reliance on governments and taxpayers to being shifted in the direction of a greater and greater reliance on parents and/or students. However, it continues to be strongly resisted in countries with traditions of free or only nominal tuition fees (sometimes constitutionally enshrined), some of which also have limited mechanisms of means-tested financial assistance or of student loans to maintain accessibility in the face of these rising costs (Johnstone, 2015).

However, many economies while adopting this cost-sharing approach were faced with unavoidable issues as pointed out by many researchers that gave some very valuable lessons for the nations planning to implement the strategy to strengthen their higher education financing. Even though the cost-sharing system has brought about some positive results, both directly and indirectly, a series of supplementary policies and a supportive environment are required to implement the system successfully. Some countries have experienced social unrest in the process of implementing similar systems. For example, a tuition increase in Japan resulted in a student strike (Tsang, 2000). Other developing countries, such as Kenya, Mexico and Brazil, also experienced student disturbances resulting from an increase in tuition fees (DeWit et al., 2005). Therefore, such challenges should be taken into account in implementing this type of educational reform (Fengliang, 2012).

The fact remains that no single remedy holds universal treatment for the financial glitches cropping up in different countries; it was the time to look for the approach that could be most beneficial under specific economic circumstances. The combining forces of weakened pricing power on the part of institutions, the continued need for postsecondary attainment growth, and more limited state funds are ushering in the need for a new funding paradigm for public higher education. This will require state and higher education officials to agree on the appropriate role for student tuition and financial aid, as well as how to account for and share financial and performance information. States and higher education institutions will need to collaborate to identify and implement strategies that improve the effectiveness and cost-efficiency of our nation's postsecondary education system. Different institution types (community colleges, bachelor's institutions, research Universities, et cetera) have unique missions and all play critical public roles. This diversity can be leveraged in different ways to maximize societal returns from available resources. Finding responsible ways to reward 
54 | MANTHAN: Journal of Commerce and Management, Volume 3, Issue 2

institutions for carrying out their defined missions, and achieving efficiencies can go a long way to improve results and reduce costs (NSBO, 2013).

\section{0 Concluding Remarks}

Even after formulation of policies based on research outcomes and recommendations squeezed out of best possible measures for testing, higher education financing is still troubled and pleads for more reforms. Empirical researchers are untiringly pursuant to find out novel alternatives for financing higher education, but the quest for a panacea to cure financial illness of financing higher education system continues. Even though there is a sharp surge in the flow of finance to higher education, there remain certain dimensions needing focus to arrive at equilibrium and to continue to endure the intermittent shocks. Out of all the dimensions, equity and efficiency in provision of higher education seemed to have suffered heavily under the stringency of funds in the sector. The most noteworthy fact is demographic alterations are massive in scale everywhere. They are bound to warrant equally or colossally larger radical changes in the higher education system, if the goal of equity and efficiency in higher education is expected to be met. And these changes cannot be brought without financial resilience.

Hence various approaches to find solutions are still sought after. Economists and researchers are still attempting to arrive at a conclusion that can be convergent as well as comprehensive in nature. Even if there are many potential alternatives available, they are low on universal applicability. Empirically it is found out that every nation spends differently on its education, especially higher education depending upon its internal economic climate. This proves that there is uniqueness in every nation's situation owing to which it needs to adopt policies which can help to produce best results.

Lastly, it is extremely crucial for every state to pass on the legacy of education which also carries the base to build a platform for further growth on it. For this every state needs constant improvisation and modifications in its strategy to ensure a continuous flow of funds. Evolution cannot be stopped or interrupted. It has to continue for development of fresh survival techniques. Higher education financing also needs constant evolutions because a single revolution would not be able to put an end to the miseries those keep creeping into its territory.

\section{References}

Alexander, F. A. (1998). Vouchers in American education: Hard legal and policy lessons from higher education, Journal of Education Finance, 24(2): 153-178. 
Asian Development Bank (2012). Financing Asian Higher Education for Inclusive Growth; available at https://www.adb.org/sites/default/files/publication/29679/countingcost.pdf (accessed on 7 September 2016).

Azad, J. L. (1989). State grants: Pattern, procedure and policies, In Higher Education: The Institutional Context, A. Singh and G. D. Sharma (Eds.), Konark Publisher, New Delhi, pp. 324-339.

Azad, J. L. (1999). Criteria based funding of higher education. Journal of Educational Planning and Administration, 13(4): 443-449.

Babbidge, H. D. (1961). Financing higher education. National Tax Association, 54: 250256.

Barr, N. (2003). Financing Higher Education: Comparing the Options, London School of Economics and Political Science, available at https://econ.lse.ac.uk/staff/nb/barr_HE_option030610.pdf (accessed on 7 September 2016).

Beviá, C. \& Iturbe-Ormaetxe, I. (2002). Redistribution and subsidies for higher education. The Scandinavian Journal of Economics, 104(2): 321-340.

Birdsall, N. (1996). Public spending on higher education in developing countries: Too much or too little? Economics of Education Review, 15(4): 407-119.

Bloch, B. W. \& Hinshaw, C. E. (1997). A prepaid tuition plan for private higher education. Journal of Education Finance, 3(1): 101-106.

Blum, V. C. (1958). Financing higher education. The Journal of Higher Education, 29(6): 309-316.

Castells, M. (1993). The University System: Engine of Development in the New World Economy. In Ransom, A. et al (Eds.) Improving Higher Education in Developing Countries, World Bank, Washington, D.C.

Daniere, A. (1972). The economics of higher education. The Annals of the American Academy of Political and Social Science, 404: 58-70. 
56 | MANTHAN: Journal of Commerce and Management, Volume 3, Issue 2

Davidson, C. (1955). Government Support of Private College and Universities, American Academy of Political Science and Social Science, 301:112-122.

Editorial. (1962). Federal tax incentives for higher education. Harvard Law Review, 76(2), 369-387.

Eicher, J (1990). The costs and financing of higher education in Europe. European Journal of Education, 33(1): 31-39.

Fengliang, Li (2012). Financing higher education: Lessons from China. Irish Educational Studies, 31(2): 191-206.

Green, R.T. (1962). The need for coordination and control in the financing of state institutions. Proceedings of the Annual Conference on Taxation under the Auspices of the National Tax Association, 55: 476-482

Hansen, W.L. (1983). Impact of student financial aid on access. Proceedings of the Academy of Political Science, 35(2): 84-96.

Hansen, W.L. \& Weisbrod, B.A (1969). The distribution of costs and direct benefits of public higher education: The case of California. The Journal of Human Resources, 4(2): 176-191.

Harmon, D. B. (1931). Some trends in financing higher education. Social Science, 6(2): 97-109.

Heim, P. (1976). Financing higher education: The challenge to state and local government, Proceedings of the Annual Conference on Taxation under the Auspices of the National Tax Association, 60: 130-138.

Hill, Jr., W.W. (1962). State supported student loan programs. Proceedings of the Annual Conference on Taxation under the Auspices of the National Tax Association, 55: 493-497.

Hollis, E. V. (1939). Recent trends in higher education, Phi Delta Kappa International, 21(8): 385-387, 391. 
Jacobs, Bas \& van Wijnbergen, Sweder J. G. (2007). Capital-market failure, adverse selection, and equity financing of higher education. FinanzArchiv / Public Finance Analysis, 63(1): 1-32.

Jenny, H. H. (1975). Financing higher education. Journal of Education Finance, 1(1): 26-35.

Johnstone, D. Bruce (2003). Cost sharing in higher education: Tuition, financial assistance, and accessibility in a comparative perspective. Sociologický Časopis / Czech Sociological Review, 39(3): 351-374.

Kane, J.T. (1990). Beyond tax relief: long-term challenges in financing higher education. National Tax Journal, 50(2): 335-349.

Kaplan, N. (1960). Research overhead and the universities. American Association for the Advancement of Science, 132(3424): 400-404.

King, R.B. (1951). Financing private colleges. Penn State University Press, 34(3):232244.

Kotey, N. (1992). Student loans in Ghana. Higher Education, 23(4): 451-459.

Krueger, A.O. (1972). Optimal investment in college instruction: Equity and efficiency: Comment. Journal of Political Economy, 80(2): S31-S33.

Levy, D. (1982). Private versus public financing of higher education: U.S. policy in comparative perspective. Higher Education, 11(6): 607-628.

Maclure, S. (1967). Financing of students: Grants or loans? The British Medical Journal, 1(5533): 166-167.

Mathew, E.T. (1996). Financial aspects of privatisation of higher education: Issues and options, Economic and Political Weekly, 31(4): 866-869.

Meck, J.F. (1955). How much-and how-should students pay for higher education? The Annals of the American Academy of Political and Social Science, 301: 166-174. 
58 MANTHAN: Journal of Commerce and Management, Volume 3, Issue 2

Merrett, S. (1967). Student finance in higher education. The Economic Journal, 77(306): 288-302.

Millet, J.D. (1955). Recent developments in financing higher education. The Annals of The American Academy of Political And Social Science, 305: 205-210.

Mridula (1985). State Funding of Universities: A Study of Maintenance Grants to Universities. Association of Indian Universities, New Delhi.

Mulugetta, Y, Saleh, D. A \& Mulugetta, A. (1997). Student aid issues at private institutions. New Directions for Institutional Research, 95:43-64.

Musgrave, R. A. (1960). Higher education and the federal budget. The Review of Economics and Statistics, 42(3): 96-101.

NASBO. (2013). Improving Postsecondary Education through the Budget Process: Challenges \& Opportunities, National Association of State Budget Officers, available at http://www.ncci-cu.org/downloads/improving.pdf (accessed on 7 September 2016).

Nwacukwu, C. (1977). Issues and problems of financing education in Nigeria. The Journal of Negro Education, 46(3): 219-229.

Orr, P. G. \& Peseau, B. A. (1979). Formula funding is not the problem in teacher education. Peabody Journal of Education, 57(1): 61-71.

Psacharopoulos, G. (2008). Funding universities for efficiency and equity: Research findings versus petty politics. Education Economics, 16(3): 245-260.

Russell, J. D. (1960). Financing higher education in the sixties. The Phi Delta Kappan, 42(1): 8-11.

Sack, S. (1961). A nineteenth-century scheme for financing higher education in Pennsylvania. History of Education Quarterly, 1(3): 50-54.

Schultz, T. W. (1968). Resources for higher education: An economist's view. Journal of Political Economy, 76(3): 327-347. 
Sharma, G. D. \& Qamar, F. (1990). Efficient utilization of resources in higher education. Journal of Education and Social Change, 4(3).

Sliger, B. F. \& Beard, T. R. (1962). State Support of Public Higher Education, Proceedings of the Annual Conference on Taxation under the Auspices of the National Tax Association, 55: 464-476.

Soper, W. W (1947). Educational costs and their analysis. American Educational Research Association, 17(2): 155-162.

Stewart, E. T. (1957). Individual giving to higher education. Phi Delta Kappa International, 38(5): 191-194.

Storm, R. \& Feiock, R. C. (1999). Economic development consequences of state support for higher education. State \& Local Government Review, 31(2): 97-105.

Thompson, D. E. (1961). Corporate giving: A partial answer to the financial needs of higher education. American Association of University Professors, 47(4): 321-324.

Tilak, J. B. G. (2003). Higher education and development in Asia. Journal of Educational Planning and Administration, 17(2): 151-173.

Tilak, J. B. G. (2005). Are we marching towards laissez-faireism in higher education development? Journal of International Cooperation in Education, 8(1): 153 - 165.

Tilak, J. B. G. \& Rani, G. (2003). Changing pattern of university finances in India. Journal of Services Research, 2(2): 5-46.

Trent, W. J. (1955). Cooperative fund raising for higher education. Journal of Negro Education, 24(1): 6-15.

Tweeten, L. (1972). Equity implications of state tuition policy and student loans: Comment. Journal of Political Economy, 80(3): S175-S177.

Varghese, N. V. (2015). Challenges of Massification of Higher Education in India, CPRHE Research Papers 1, CPRHE, NUEPA, New Dehli. 
60 | MANTHAN: Journal of Commerce and Management, Volume 3, Issue 2

Wigger, B. (2001). Higher education financing and income redistribution, FinanzArchiv/ Public Finance Analysis, 58(1): 48-59.

Woodhall, M. (1992). Student loans in developing countries: Feasibility, experience and prospects for reform. Higher Education, 23(4): 347-356. 